\title{
Casein and whey exert different effects on plasma amino acid profiles, gastrointestinal hormone secretion and appetite
}

\author{
W. L. Hall*, D. J. Millward, S. J. Long and L. M. Morgan \\ Centre for Nutrition and Food Safety, School of Biomedical and Life Sciences, University of Surrey, Guildford, \\ Surrey GU2 7XH, UK \\ (Received 4 April 2002 - Revised 11 July 2002 - Accepted 6 September 2002)
}

\begin{abstract}
Protein, generally agreed to be the most satiating macronutrient, may differ in its effects on appetite depending on the protein source and variation in digestion and absorption. We investigated the effects of two milk protein types, casein and whey, on food intake and subjective ratings of hunger and fullness, and on postprandial metabolite and gastrointestinal hormone responses. Two studies were undertaken. The first study showed that energy intake from a buffet meal ad libitum was significantly less $90 \mathrm{~min}$ after a $1700 \mathrm{~kJ}$ liquid preload containing $48 \mathrm{~g}$ whey, compared with an equivalent casein preload $(P<0.05)$. In the second study, the same whey preload led to a $28 \%$ increase in postprandial plasma amino acid concentrations over $3 \mathrm{~h}$ compared with casein (incremental area under the curve (iAUC), $P<0.05$ ). Plasma cholecystokinin (CCK) was increased by $60 \%$ (iAUC, $P<0.005$ ), glucagon-like peptide (GLP)-1 by $65 \%$ (iAUC, $P<0.05$ ) and glucose-dependent insulinotropic polypeptide by $36 \%$ (iAUC, $P<0.01$ ) following the whey preload compared with the casein. Gastric emptying was influenced by protein type as evidenced by differing plasma paracetamol profiles with the two preloads. Greater subjective satiety followed the whey test meal $(P<0 \cdot 05)$. These results implicate post-absorptive increases in plasma amino acids together with both CCK and GLP1 as potential mediators of the increased satiety response to whey and emphasise the importance of considering the impact of protein type on the appetite response to a mixed meal.
\end{abstract}

Dietary protein: Satiety: Cholecystokinin: Glucagon-like peptide-1: Postprandial amino acids

It is well established that protein is more satiating, $\mathrm{kJ}$ for $\mathrm{kJ}$, than carbohydrate or fat (Booth et al. 1970; De Castro, 1987; Barkeling et al. 1990; Hill \& Blundell, 1990; Johnstone et al. 1996; Stubbs et al. 1996; Vandewater \& Vickers, 1996; Porrini et al. 1997; Latner \& Schwartz, 1999). However, the satiating influence of protein is variable. One influence is the habitual protein intake that affects the satiating response to a standard protein meal in individuals. Thus, the satiating response to a standard protein meal is less in subjects previously adapted to a high- compared with a low-protein intake (Long et al. 2000). While the mechanism for this has not been demonstrated, one possibility relates to a more rapid postprandial clearance and oxidation of amino acids (AA) in subjects adapted to higher protein intakes. Another influence is the protein itself. There is some evidence that different protein sources may differ in their satiating capacity (Uhe et al.
1992), although not all observers report differences (Lang et al. 1998, 1999). If the extent of postprandial excursions in circulating AA levels influence satiety (the basis of Mellinkoff's original aminostatic concept (Mellinkoff et al. 1956)), then factors that influence dietary protein digestion and absorption could influence the relative satiating influence of proteins. The digestion and absorption of whey and casein differ in that casein, unlike whey, coagulates in the stomach due to its precipitation by gastric acid (Billeaud et al. 1990; Miller et al. 1990). As a result, overall gastric emptying time for casein is longer and there is a smaller postprandial increase in plasma AA compared with the non-coagulating whey protein. The concept of 'fast' and 'slow' proteins was introduced by Boirie et al. (1997) to describe these differences in digestion and absorption of whey and casein. It might be predicted therefore that whey, a 'fast' protein, would be more satiating than casein.

\footnotetext{
Abbreviations: AA, amino acid; CCK, cholecystokinin; GIP, glucose-dependent insulinotropic polypeptide; GLP, glucagon-like peptide; VAS, visual analogue scale.

* Corresponding author: Dr W. L. Hall, fax +44 1483 576978, email w.hall@ surrey.ac.uk
} 
The aims of the present study were therefore: (1) to test the hypothesis described earlier; (2) to investigate possible physiological and metabolic bases for any differences in appetite found. The effects on appetite of isoenergetic liquid preloads containing either casein or whey were investigated in normal-weight healthy volunteers, by measuring their relative influence on food intake and subjective appetite ratings. In a separate experiment, postprandial profiles of circulating hormones and metabolites were measured following consumption of the two protein preloads. In particular, the potential roles of cholecystokinin (CCK) and glucagon-like peptide (GLP)-1, two gastrointestinal hormones that have both been previously shown to play an important role in satiety in human subjects (Ballinger \& Clark, 1994; Lieverse et al. 1994; Gutzwiller et al. 1999; Verdich et al. 2001), were investigated.

\section{Materials and methods}

Two studies were performed both involving a randomised, single-blind, within-subject experimental design. In the first, investigations were limited to study of the appetite responses to casein and whey preloads by means of subjective ratings and measurement of food intake ad libitum during a buffet-style meal. In the second study, the focus was on the physiological and biochemical sequelae of the two protein pre-meals and a subsequent standard meal, although subjective appetite ratings were also measured.

\section{Subjects}

All subjects were non-dieting and non-smokers. No subjects had special dietary requirements, significant current or previous medical history, or took medication apart from oral contraceptives. Written informed consent was obtained from all participants and the study protocol was approved by the University of Surrey Advisory Committee on Ethics.

Subjects in study 1 consisted of sixteen lean healthy volunteers (eight female and eight male) who were recruited from the University of Surrey, mean age 22 (SD 2.0) years and mean BMI 21.7 (SD $2 \cdot 0$ ) $\mathrm{kg} / \mathrm{m}^{2}$. Subjects in study 2 were nine lean healthy volunteers (eight female and one male) recruited from the University of Surrey, mean age 25 (SD 2.4) years and mean BMI 22.6 (SD 1.5) $\mathrm{kg} / \mathrm{m}^{2}$. In each case, potential volunteers were excluded if they consumed $>20 \%$ energy intake as protein (assessed by $4 \mathrm{~d}$ food diary in study 1 , and $7 \mathrm{~d}$ food diary in study 2 ) or if their mean score was $>3.0$ for the Dutch Eating Behaviour Questionnaire (van Strien et al. 1986).

\section{Preloads, meals and measurement of appetite}

Casein and whey liquid preloads. Identical isoenergetic high-protein liquid preloads, containing about $1700 \mathrm{~kJ}$ and $48 \mathrm{~g}$ protein, were used in both studies. The liquid preload was formulated using commercially available powdered whey (Prolab Nutrition, Bloomfield, CT, USA) or casein (Tropicana World Ltd, Birmingham, UK), protein, double cream and maltodextrin made up to $450 \mathrm{ml}$ with water. Macronutrient and AA compositions of the two
Table 1. Composition of whey and casein protein powder

\begin{tabular}{lrr}
\hline & Whey & Casein \\
\hline Energy $(\mathrm{kJ} / \mathrm{kg})$ & 17270 & 14980 \\
Protein $(\mathrm{g} / \mathrm{kg})$ & 762 & 850 \\
Carbohydrate $(\mathrm{g} / \mathrm{kg})$ & 87 & 12 \\
Fat $(\mathrm{g} / \mathrm{kg})$ & 48 & 15 \\
Amino acids $(\mathrm{g} / \mathrm{kg})$ & & \\
Alanine & 48 & 31 \\
Arginine & 23 & 38 \\
Aspartic acid & 102 & 73 \\
Cysteine & 12 & 4 \\
Glutamic acid & 172 & 223 \\
Glycine & 20 & 19 \\
Histidine & 16 & 32 \\
Isoleucine & 84 & 58 \\
Leucine & 105 & 101 \\
Lysine & 91 & 83 \\
Methionine & 16 & 30 \\
Phenylalanine & 31 & 54 \\
Proline & 61 & 105 \\
Serine & 52 & 63 \\
Threonine & 62 & 46 \\
Tryptophan & 21 & 14 \\
Tyrosine & 24 & 58 \\
Valine & 60 & 74 \\
\hline
\end{tabular}

protein powders are shown in Table 1 and the macronutrient composition and energy content of the final formulated preloads in Table 2 . In addition, in study 2 , the liquid preloads also contained $1.5 \mathrm{~g}$ paracetamol (Panadol; GlaxoSmithKline, Brentford, Essex, UK) in order to monitor gastric emptying (Heading et al. 1973).

Meals and appetite measurement. Food intake after consumption of the preload was assessed in study 1 using a buffet test meal ad libitum (Hill et al. 1995) that enabled subjects to choose from a range of familiar foods, appropriate to the time of day. Subjects were asked to rank various buffet food items in order of preference. They were then offered their second and third choices of sandwich fillings and food types. The total energy available from the buffet ranged from $10751 \mathrm{~kJ}$ to $12611 \mathrm{~kJ}$ (protein 13, fat 38, carbohydrate $49 \%$ energy) depending on subjects' preferences and the subsequent food items offered. The number and range of food items presented to each subject was identical on each test occasion. The buffet food was weighed before and re-weighed after each subject had finished eating, to allow calculation of energy and macronutrient intake.

A cold lunch was supplied in study 2 based on the subjects' food choices (obtained during recruitment). This was standardised to supply each subject with $42 \mathrm{~kJ} / \mathrm{kg}$ body weight, and with each component of the meal making up the same proportion of total energy intake for each individual (calculated on the basis of the nutritional composition of the foods). The meal choices were similar to those offered to subjects in the buffet-style meal used in study 1. Subjects were instructed to consume all the food that was offered.

Subjective assessment of hunger, satiety and desire to eat was made in both studies using subjective visual analogue scales (VAS) (Hill et al. 1995). Each scale consisted of a $100 \mathrm{~mm}$ line anchored at either end with 
Table 2. Composition of liquid test meals

\begin{tabular}{|c|c|c|c|c|c|c|}
\hline \multirow[t]{2}{*}{ Test meal. . } & \multicolumn{3}{|c|}{ Casein* $^{*}$} & \multicolumn{3}{|c|}{ Whey† } \\
\hline & $g$ & Macronutrient (g) & Energy (kJ) & g & Macronutrient (g) & Energy (kJ) \\
\hline Protein powder & 57 & $48 \ddagger$ & 858 & 63 & $48 \ddagger$ & 1021 \\
\hline Double cream & 23 & $11 \S$ & 414 & 19 & $9 \S$ & 339 \\
\hline Maltodextrin & 24 & $24 \|$ & 402 & 20 & $20 \|$ & 335 \\
\hline
\end{tabular}

* Total energy $1674 \mathrm{~kJ}$.

†Total energy $1695 \mathrm{~kJ}$.

$\ddagger$ Protein.

$\S$ Fat.

|| Carbohydrate.

extreme statements; for example the scale 'how hungry do you feel?' ranged from 'not at all hungry' to 'as hungry as I have ever felt'. Subjects were instructed to rate themselves by marking the scale at the point that was most appropriate to their feeling at that time. Ratings on the scales were converted to a score $(\mathrm{mm})$ for statistical analysis of the appetite responses to each treatment.

\section{Study protocols}

Each study was a randomised, single-blind, within-subject experimental design involving the testing of either whey or casein liquid preloads on two separate days. Subjects were instructed to avoid alcohol and high-protein meals the evening before and until the study, and in study 2 to refrain from taking any paracetamol tablets or paracetamol-containing products for the previous $24 \mathrm{~h}$.

Study 1. Subjects were instructed to consume their usual breakfast before 09.30 hours, and to eat the same cereal-based breakfast on each test occasion. Individuals were offered a liquid casein or whey preload at 11.30 hours on separate occasions $7 \mathrm{~d}$ apart. This was presented in a black opaque beaker with a lid and ingested through a straw, thus masking any visible difference in the appearance of the preloads. VAS ratings were completed before and after consumption of the drink, and at 20 min intervals for the next $3 \mathrm{~h}$. Ninety minutes after the liquid preload, subjects were offered the pre-weighed buffet-style test meal ad libitum, from which energy and macronutrient intakes were calculated.

Study 2. The protocol for the investigation of physiological mechanisms was designed to emulate the procedures in study 1 as closely as possible. On the day of each study, subjects consumed a standard breakfast consisting of cornflakes and skimmed milk before 08.00 hours, and then consumed nothing until the study in order that all volunteers started the study in a similar metabolic state. Subjects consumed the liquid casein or whey preload at 11.00 hours. Venous blood samples were taken before, and at 5, 15, 35, 45, 60, 75, 90, 120 and $180 \mathrm{~min}$ after preload consumption from a cannulated forearm vein, for the measurement of plasma paracetamol, AA, glucose, insulin, GLP-1, glucose-dependent insulinotropic polypeptide (GIP) and CCK. The standard lunch was provided $90 \mathrm{~min}$ after the liquid preload. Subjects were instructed to eat all that was provided as quickly as was comfortable and blood sampling was continued for another 90 min following lunch.

\section{Biochemical analyses}

Blood samples were taken at regular intervals into tubes containing preservatives. They were kept on ice before centrifugation at $4^{\circ} \mathrm{C}$ for $10 \mathrm{~min}$ at $1550 \mathrm{~g}$ to separate the plasma. Blood was collected into fluoride oxalate tubes before centrifugation for glucose measurement, and into lithium heparin tubes for AA, insulin and GIP measurement. Blood was collected into lithium heparin tubes containing aprotinin (200 kIU/ml blood) for GLP-1 measurement. The separated plasma was frozen at a temperature of $-20^{\circ} \mathrm{C}$. For CCK measurement, blood was collected into chilled $5 \mathrm{ml}$ EDTA tubes containing sodium acetate buffer $(1 \mathrm{ml}$ sodium acetate buffer $(175 \mathrm{mM}-\mathrm{NaCl}$, $63 \mathrm{~mm}-\mathrm{NaOH}, 30 \mathrm{~mm}$-acetic acid, adjusted to $\mathrm{pH} 3.6$ with $\mathrm{HCl} / 4 \mathrm{ml}$ blood). The separated plasma was added to ethanol (plasma-ethanol (980 g/l) 1:2, v/v) on the study day, vortexed, then centrifuged at $1550 \mathrm{~g}$ for $15 \mathrm{~min}$. The supernatant fraction was transferred into assay tubes, immediately dried under low vacuum and the tubes stored at $-80^{\circ} \mathrm{C}$ until assay. Plasma paracetamol and glucose were measured using commercial assay kits (Cambridge Life Sciences (Ely, Cambridge, UK) and Randox (Crumlin, Co. Antrim, UK) respectively) with an automated Cobas Mira biochemical analyser (Roche Products Ltd., Welwyn Garden City, Hertfordshire, UK). Plasma AA were measured using Waters PICO-TAGTM Amino Acid Analysis System (Waters, MA, USA), which involves the pre-column derivatisation of the sample with phenylisothiocyanate followed by reversed-phase HPLC. Plasma insulin, GIP, GLP-1 and CCK were analysed using radioimmunoassay techniques (Morgan et al. 1978; Beardshall et al. 1992; Elliott et al. 1993; Hampton \& Whithey, 1993). Inter-assay CV for metabolites were $<15 \%$ for insulin, GIP, GLP-1 and CCK. Intra-assay CV were smaller. All samples from an individual subject were analysed within the same assay.

\section{Statistical analysis}

Food intake ad libitum from the buffet meal was analysed using Student's paired $t$ test. VAS ratings and biochemical measurements were analysed by repeated-measures analysis of covariance with type of protein and time as 
within-subjects factors. Baseline values were treated as covariates or, for plasma AA concentrations, an ANOVA was carried out on the change from baseline values ( $x$ - baseline value). All results are expressed as mean values with their standard errors unless otherwise stated. $P$ values $<0.05$ were considered statistically significant.

\section{Results}

Study 1

Energy intake ad libitum for the buffet meal is shown in Fig. 1, including the proportion of energy consumed as carbohydrate, fat and protein. Total energy intake was significantly lower following the whey protein than following the casein protein preload (3676 (SEM 359) v. 4537 (SEM $528) \mathrm{kJ}$ respectively, $P<0.05$ ). This difference was reflected in intakes of all three macronutrients. Subjective appetite ratings (VAS ratings) for hunger, desire to eat and fullness varied significantly over time $(P<0 \cdot 001)$. However, no significant differences were found due to protein type (results not shown).

\section{Study 2}

Appetite. VAS ratings for hunger, desire to eat and fullness varied significantly with time $(P<0 \cdot 001)$. Desire to eat (Fig. 2) was significantly reduced by whey protein compared with casein following the standard lunch $(P<0.005)$, an effect that failed to reach significance for hunger ratings $(P=0.061)$. Fullness (Fig. 3) was significantly increased following the liquid whey preload compared with casein for the duration of the $180 \mathrm{~min}(P<0.05)$.

Plasma metabolites. AA profiles were measured for thirteen AA. Total AA profiles are shown in Fig. 4. There was a significant preload $\times$ time interaction for plasma total AA $(P<0.005)$ due to higher circulating AA

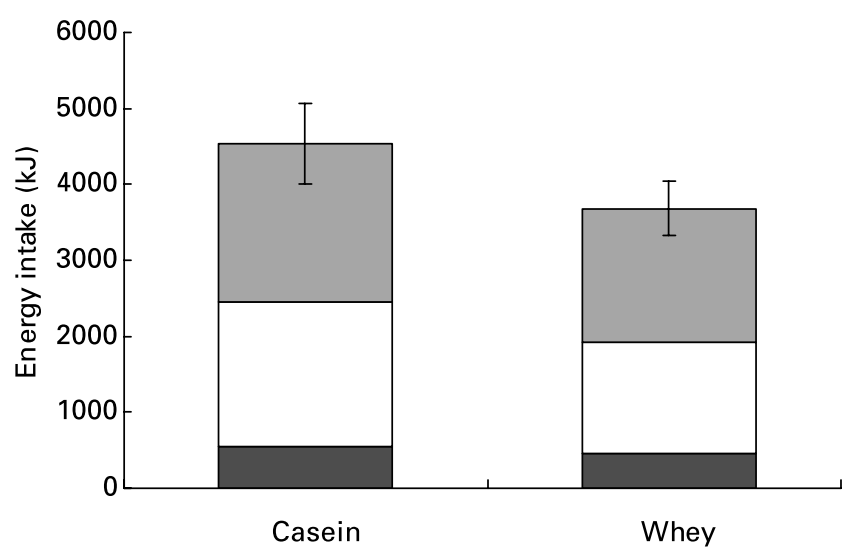

Fig. 1. Study 1: effects of $1700 \mathrm{~kJ}$ preloads ( $48 \mathrm{~g}$ casein or whey) on energy intake (including the proportions of total energy intake from protein, fat and carbohydrate) from a buffet lunch ad libitum 90 min later. $\square$, Carbohydrate; $\square$, fat; $\square$, protein. For details of liquid test meals, subjects and procedures, see Tables 1 and 2 and p. 240. Values are means for sixteen subjects with their standard errors shown by vertical bars. There was a significant reduction in energy intake following the whey compared with the casein preload $(P<0.05)$. concentrations during the second and third hours following the liquid whey preload compared with casein. Increases in postprandial plasma profiles of the branched-chain AA following the whey compared with the casein preload were particularly marked and highly significant. Increases (\%) following whey compared with casein over $180 \mathrm{~min}$ were: valine $34(P<0.001)$, isoleucine $102(P<0.00005)$ and leucine $70 \quad(P<0.0000001)$, and threonine was increased by $95(P<0 \cdot 00005)$. No significant difference was observed in plasma glucose response following the two different protein liquid preloads.

Plasma hormones. There were significantly greater increases in overall plasma concentrations of GIP $(P<0.005)$, GLP-1 $(P<0 \cdot 05)$ and CCK $(P<0 \cdot 01)$ following the whey preload compared with casein (Figs 5, 6 and 7), but postprandial increases in plasma insulin did not differ in response to the two protein preloads.

Gastric emptying. Plasma paracetamol concentrations following casein and whey preloads demonstrated a significant preload $\times$ time effect $(P<0.05)$. This reflects a difference in rates of gastric empting between the two preloads, with a faster initial rise in plasma paracetamol concentrations following the casein meal and then a levelling off compared with the whey preload.

\section{Discussion}

The present study extends our interest in aminostatic mechanisms of appetite regulation (Long et al. 2000) to an examination of the differing satiating capacity of various protein sources (Uhe et al. 1992; Lang et al. 1998, 1999). Here we focus on the 'fast' and 'slow' protein concept introduced by Boirie et al. (1997) to describe the differences between whey and casein in their digestion and absorption. Our present results confirm that casein, as a coagulating protein, exhibits a slower rate of gastric emptying and mediates lower postprandial excursions of plasma AA concentrations compared with the non-coagulating protein whey (Boirie et al. 1997). On the basis of Mellinkoff's original aminostatic concept (Mellinkoff et al. 1956), a larger rise in plasma AA would increase satiety, and this is demonstrated by our present findings.

Our experimental design involved an initial study of appetite responses alone (study 1) followed by attempts to identify physiological and biochemical responses (study 2). We assumed that the serial blood sampling might make it more difficult to identify appetite responses, so we made no attempt to measure food intake ad libitum in study 2, limiting our measures to observations of subjective differences in appetite (VAS scores). The relative palatability of the casein and whey preloads was not measured by VAS or any other methodology. However, the presentation of the two meals in black opaque beakers with lids and straws minimised the visual and olfactory stimulus, and the protein powder formulations used were both fruit-flavoured, so there was no marked difference between the sensory qualities of the preloads. If there was a difference in palatability, the buffet-style ad libitum test meal in study 1 was $90 \mathrm{~min}$ after ingestion, and any influences on satiety resulting from the palatability of the preloads would have been minimal by then. In study 2 , 


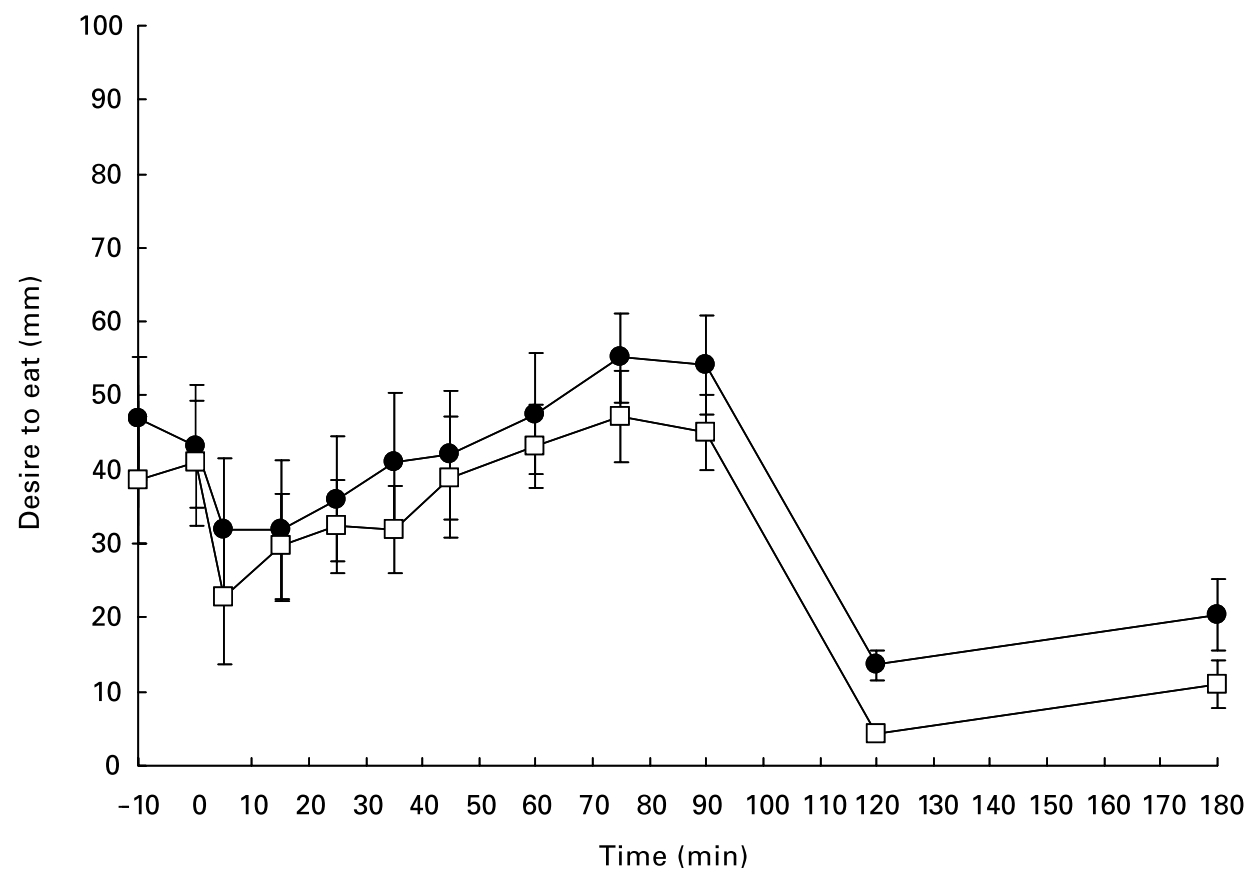

Fig. 2. Study 2: effects of $1700 \mathrm{~kJ}$ preloads ( $48 \mathrm{~g}$ casein or whey) on desire to eat ratings (visual analogue scale). $\bullet$, Casein; $\square$, whey. The liquid test meal was given at 0 min and the standard lunch at $90 \mathrm{~min}$. For details of liquid test meals, subjects and procedures, see Tables 1 and 2 and p. 240. Values are means for nine subjects with their standard errors shown by vertical bars. There was a significant reduction in desire to eat after the whey preload following the standard lunch (analysis of covariance $90-180 \mathrm{~min}, P<0.005)$.

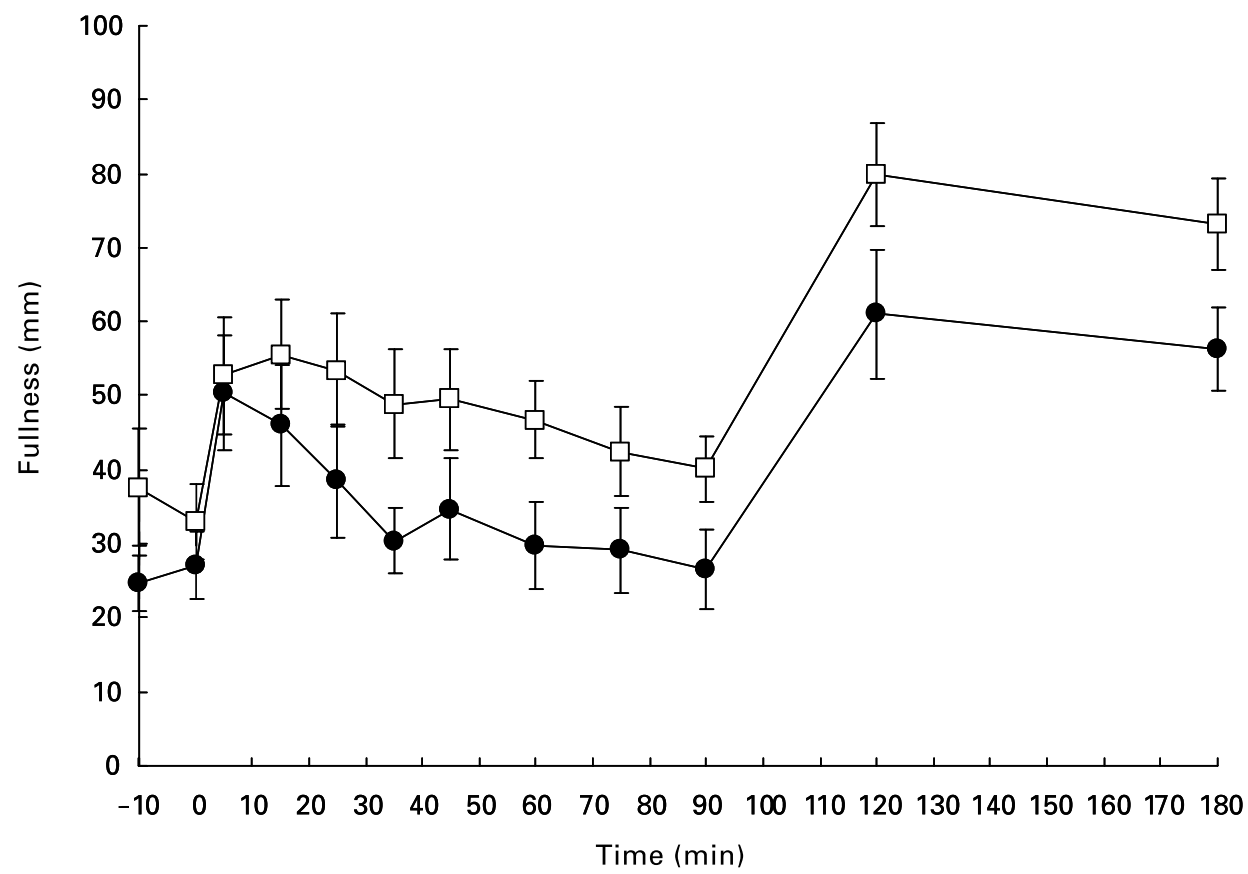

Fig. 3. Study 2: effects of $1700 \mathrm{~kJ}$ preloads ( $48 \mathrm{~g}$ casein or whey) on fullness ratings (visual analogue scale). $\bullet$, Casein; $\square$, whey. The liquid test meal was given at $0 \mathrm{~min}$ and the standard lunch at $90 \mathrm{~min}$. For details of liquid test meals, subjects and procedures, see Tables 1 and 2 and p. 240. Values are means for nine subjects with their standard errors shown by vertical bars. There was a significant increase in fullness after the whey preload (analysis of covariance $0-180 \mathrm{~min}, P<0.05$ ). 


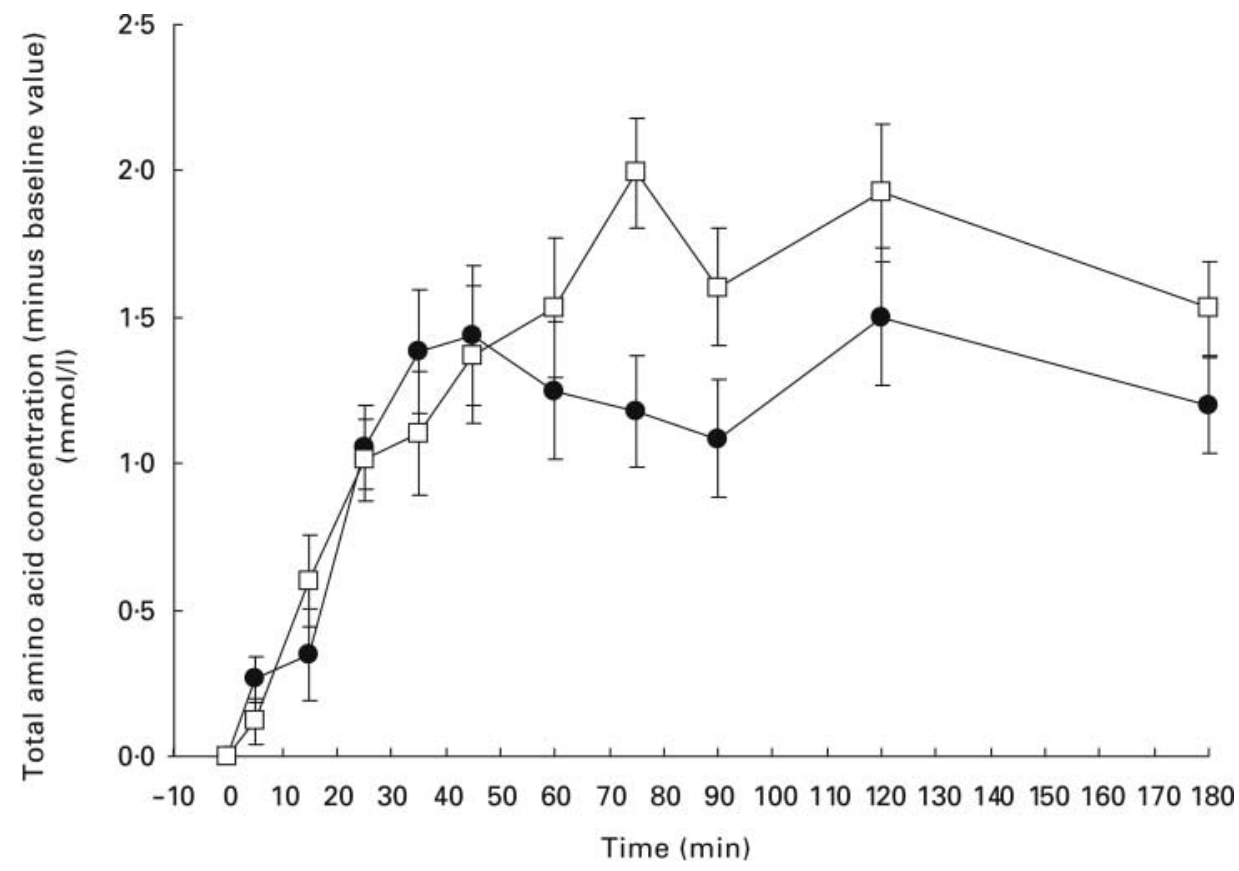

Fig. 4. Study 2: effects of $1700 \mathrm{~kJ}$ preloads ( $48 \mathrm{~g}$ casein or whey) on plasma total amino acids. $\bullet$, Casein; $\square$, whey. The liquid test meal was given at $0 \mathrm{~min}$ and the standard lunch at $90 \mathrm{~min}$. For details of liquid test meals, subjects and procedures, see Tables 1 and 2 and p. 240. Values are means for nine subjects with their standard errors shown by vertical bars. There was a significant increase in total amino acid concentration following the whey preload (ANOVA 1-180 min, treatment $\times$ time interaction, $P<0.005$ ).

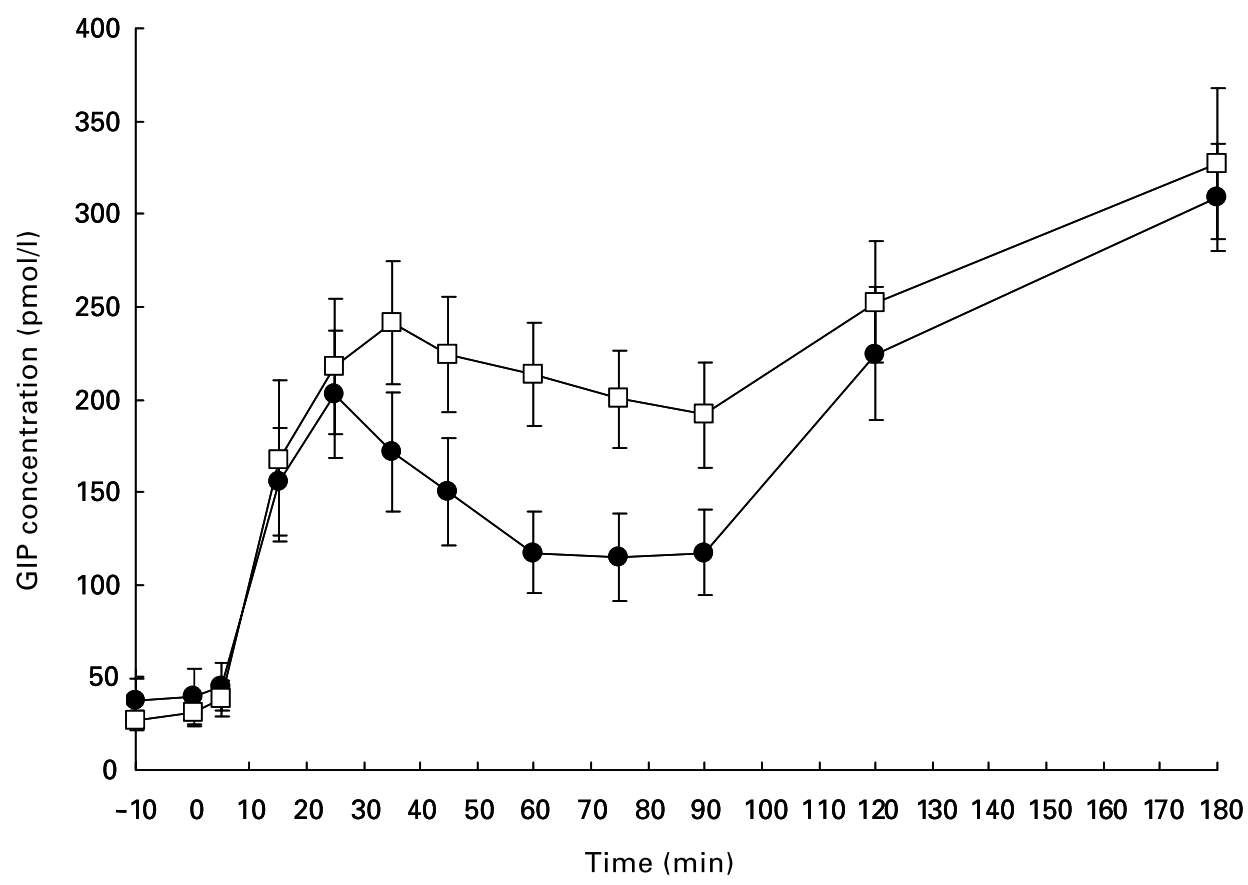

Fig. 5. Study 2: effects of $1700 \mathrm{~kJ}$ preloads ( $48 \mathrm{~g}$ casein or whey) on glucose-dependent insulinotropic polypeptide (GIP). $\bullet$, Casein; $\square$, whey. For details of liquid test meals, subjects and procedures, see Tables 1 and 2 and p. 240. Values are means for nine subjects with their standard errors shown by vertical bars. There was a significant increase in plasma GIP after the whey preload (analysis of covariance $0-180 \mathrm{~min}, P<0.005)$. 


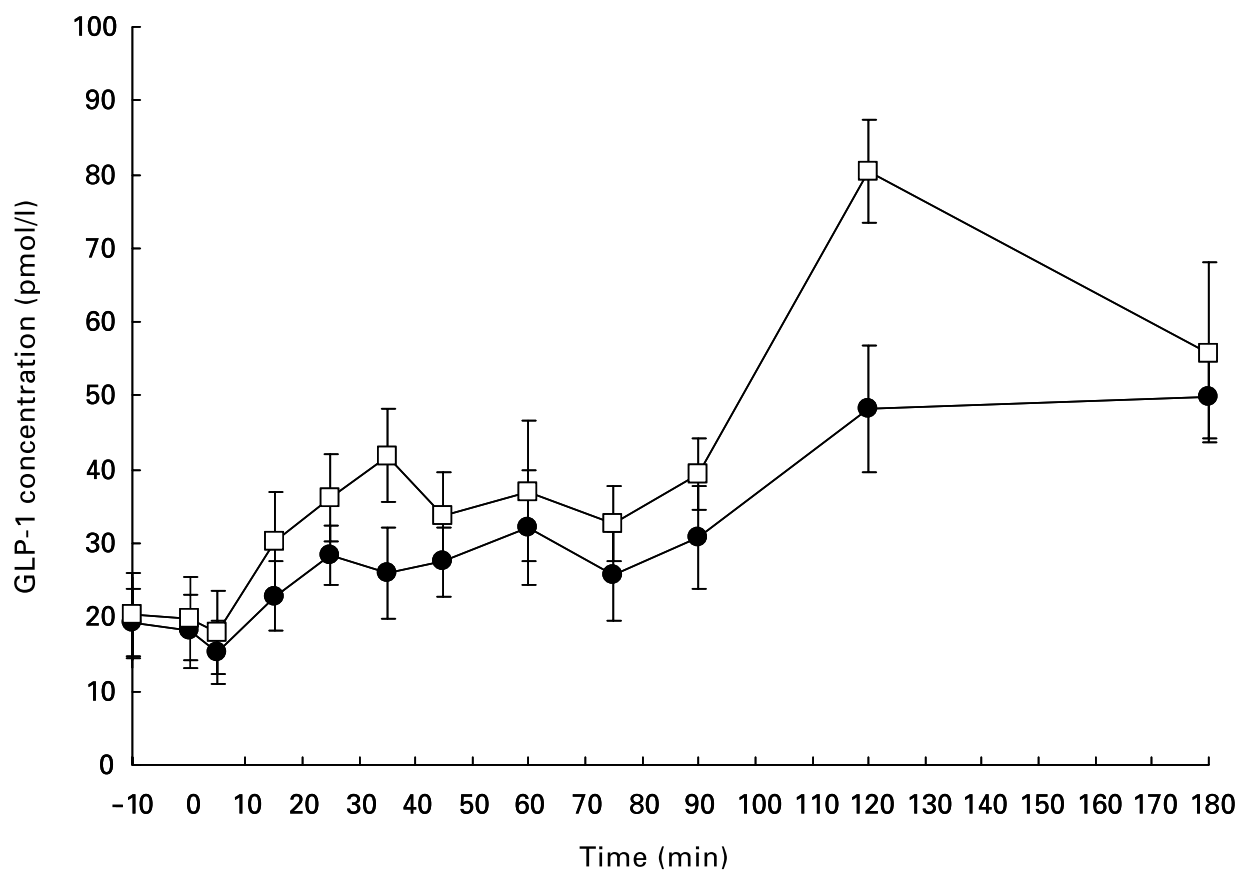

Fig. 6. Study 2: effects of $1700 \mathrm{~kJ}$ preloads ( $48 \mathrm{~g}$ casein or whey) on plasma glucagon-like peptide (GLP)-1. - Casein; $\square$, whey. For details of liquid test meals, subjects and procedures, see Tables 1 and 2 and p. 240. Values are means for nine subjects with their standard errors shown by vertical bars. There was a significant increase in plasma GLP-1 after the whey preload (analysis of covariance $0-180 \mathrm{~min}, P<0.05)$.

the largest differences in subjective appetite ratings were also observed following the standardised lunch at $90 \mathrm{~min}$.

The $19 \%$ reduction in food intake ad libitum following a liquid whey preload compared with the casein in study 1 clearly demonstrated that a whey-based liquid meal has a greater satiating efficiency than a casein-based liquid meal. Although no differences in subjective measures of appetite were shown in study 1 , in study 2 significant

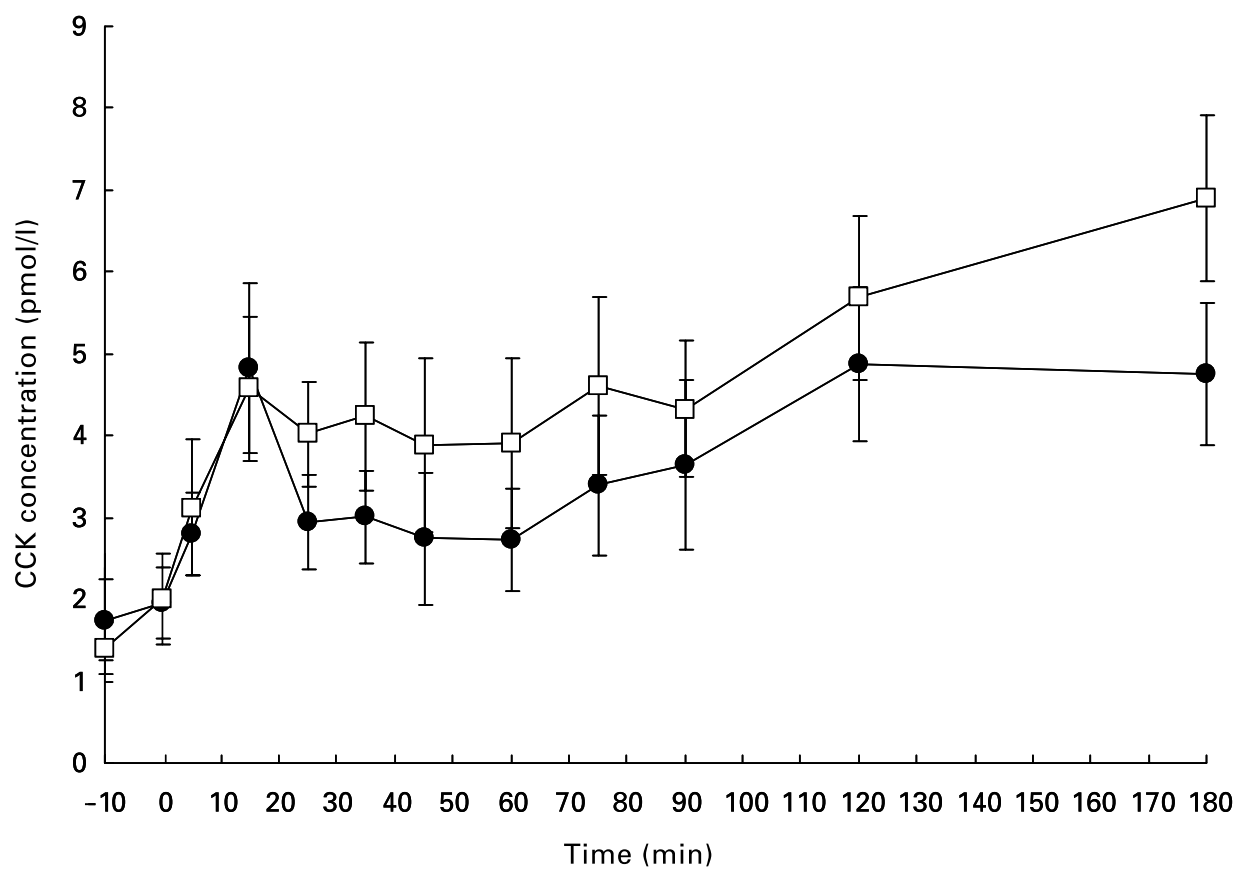

Fig. 7. Study 2: effects of $1700 \mathrm{~kJ}$ preloads ( $48 \mathrm{~g}$ casein or whey) on cholecystokinase (CCK). -, Casein; $\square$, whey. The liquid test meal was given at $0 \mathrm{~min}$ and the standard lunch at $90 \mathrm{~min}$. For details of liquid test meals, subjects and procedures, see Tables 1 and 2 and p. 240. Values are means for nine subjects with their standard errors shown by vertical bars. There was a significant increase in plasma CCK after the whey preload (analysis of covariance $0-180 \mathrm{~min}, P<0.01$ ). 
differences were observed. Thus, the whey preload resulted in increased fullness for the duration of the study and suppression of both hunger and desire to eat each following the standardised lunch-type meal. We interpret our inability to detect differences in the VAS scores in study 1 as reflecting the difficulty of quantifying this measure of appetite (Rogers, 1993; Hill et al. 1995; Green \& Blundell, 1996; Flint et al. 2000; Stubbs et al. 2000). While all subjects appeared motivated and compliant with the experimental procedures, the subject groups in the two studies did differ to some extent. Subjects in study 2 were slightly but significantly older (mean age $25 v$. 22 years, $P<0.037$ ). In study 2, unlike study 1 , subjects were compensated financially for their time and the cannulation procedures. We do not know whether these factors influenced the subjects' use of the VAS ratings. However, the largest differences in subjective appetite ratings found in study 2 were recorded following the standardised lunch. These differences are likely to have been obscured in study 1 since subjects were allowed to eat ad libitum and therefore ate different amounts at each study session. The differences in hunger and desire to eat were mainly evident following the standard lunch, whereas subjective ratings of fullness were different throughout the $180 \mathrm{~min}$. This observation reflects the fact that 'hunger' and 'satiety' are distinct sensations and should not be regarded as simply the two extremes of a continuum. For example, the initiation of an eating episode does not wholly rely on hunger sensations, since the sensory properties of a food can stimulate food intake even when satiety signals are present. The fact that the protein preloads were administered as a covert liquid meal rather than a more customary solid meal may have meant that the cognitive and sensory stimulus that normally inhibits desire to eat was repressed until the consumption of a more familiar solid meal, the standard lunch. Sensations of fullness, however, are strongly determined by sensations of gastric distension, and this may account for the apparently consistent difference in satiation between the two preloads throughout the whole $180 \mathrm{~min}$ of the study.

In the experiments presented here, a difference in food intake or subjective satiety ratings was observed during a set period of $180 \mathrm{~min}$ following the casein and whey preloads. It is not clear from these present studies however, whether these differences would persist beyond that time period, or in fact whether the 'fast' protein would prove to be less satiating in the longer term than the 'slow' protein. Subjective fullness ratings and plasma CCK concentrations were still significantly increased following the whey at $180 \mathrm{~min}$ (analysis of covariance, $P<0.01$ and $P<0.05$ respectively), which could potentially impact satiety at the next meal. This suggests that the satiating capacity of whey could be maintained over a longer time-period than included in the current work. Longerterm studies are needed to address the question of whether whey protein is more satiating than casein over a day, or whether there would be a compensatory increase in food intake at the next meal, in which case there may be no difference in total food intake.

As judged by the plasma paracetamol profiles, an index of gastric emptying, differences in the gastric emptying profiles of the liquid casein and whey preloads occurred, although the nature of these differences was complex. Initial paracetamol absorption was faster following casein, but peak circulating concentrations were higher with whey. The most likely explanation of this pattern is that after the casein protein had precipitated into curds in the stomach, the solubilised paracetamol in the liquid compartment of the meal was emptied and absorbed rapidly, but the slow emptying of the solid casein curds maintained paracetamol absorption with a plateau in plasma concentrations. Indeed, it is possible that the whey meal emptied homogeneously at a steady rate, with a more even dispersion of the lipid and aqueous phases containing the carbohydrate and protein in the whey liquid meal, whereas the casein meal emptied in a biphasic manner due to its transformation to a solid-liquid meal, with the liquid component emptying earlier. Despite the apparent differences in gastric emptying rates of the two preloads, the time course of plasma glucose and insulin concentrations were not significantly different, suggesting that carbohydrate emptied at a near uniform rate with the liquid component of the casein meal. This is in contrast to previous reports of differences in plasma insulin levels following different meal proteins (Gannon et al. 1988; Hubbard et al. 1989; Lang et al. 1999). Both insulin and glucose have been implicated in the control of appetite (Woods \& Porte, 1983; Campfield \& Smith, 1990); however, in the present study, it is unlikely that the observed differences in appetite could have been mediated by either glucose or insulin levels. This identifies variation in either protein- or fatmediated mechanisms of satiety as responsible for the satiating effect of whey.

The marked differences in circulating postprandial AA levels observed following the two protein preloads point to some aminostatic mechanism of appetite regulation as a likely explanation of the differences in appetite observed with the two proteins. Postprandial peripheral AA profiles are likely to reflect rates of digestion, absorption and first pass metabolism in the enterocyte and liver in addition to the AA composition of the proteins. The greatest differences between whey and casein AA composition $(\mathrm{g} / \mathrm{kg})$ were for arginine, methionine, phenylalanine, proline and tyrosine, in each case $>50 \%$ more in casein compared with whey. Just under half of the plasma AA measured (five out of thirteen) showed an overall greater plasma response to the whey preload. The remainder showed no significant differences in their profiles throughout the study with the exception of proline, which significantly increased following the casein meal, probably reflecting the higher proline content of casein protein. Phenylalanine, whose effects on satiety are thought to be potent (Gibbs \& Smith, 1977; Muurahainen et al. 1988; Ballinger \& Clark, 1994; Rogers et al. 1995), showed no significant differences in plasma levels following the two test meals, again probably due to the greater phenylalanine content of casein. Tryptophan, an AA frequently linked with appetite regulation (Wurtman et al. 1981; Hrboticky et al. 1985; Hill \& Blundell, 1988), could not be measured using our methodology.

The gastrointestinal hormones CCK and GLP-1 are secreted in response to protein ingestion (Hopman et al. 
1985; Elliott et al. 1993). CCK is stimulated by the entry of protein into the duodenum (Go et al. 1970), and GLP-1 secretion is influenced by the rate of gastric emptying (Schirra et al. 1996). Both hormones have previously both been shown to play an important role in satiety in human subjects (Ballinger \& Clark, 1994; Lieverse et al. 1994; Gutzwiller et al. 1999; Verdich et al. 2001). In the current study, we have investigated the potential role of these gastrointestinal hormones in mediating differences in appetite following ingestion of casein or whey. Both CCK and GLP-1 responses are consistent with a role in the greater satiating influence of whey, since both were increased more following the whey rather than casein preload. We hypothesised that if the whey protein preload was emptied from the stomach more rapidly than the casein protein, the protein-induced CCK and GLP-1 responses would be larger following the whey preload, and this indeed appeared to be the case. However, the degree to which the higher plasma CCK and GLP-1 concentrations were a result of the fat component or the protein component of the whey meal was not clear. If it is assumed that the mixture emptying into the duodenum during the 90 min pre-standard lunch study period contained a greater proportion of protein per $\mathrm{ml}$ following the whey preload compared with the casein, then it is likely that the higher CCK and GLP-1 levels in the plasma were due to the greater secretagogue effect of whey protein. However, secretion of the gastrointestinal hormone GIP was also greater following the whey preload. GIP secretion is not stimulated by protein (Elliott et al. 1993); on an isoenergetic basis, fat is the most potent stimulator of GIP secretion in human subjects (Penman et al. 1981). GIP secretion is a marker for carbohydrate and fat absorption (Morgan et al. 1988), suggesting that a greater proportion of fat, in addition to protein, was being emptied and absorbed immediately following the whey preload. This may have been a result of incorporation of fat into the casein curds or possibly a generally stronger inhibition of gastric emptying through a neural reflex response to the retention of solid matter in the fundus.

In conclusion, a preload drink of whey protein has been shown to be more satiating, and to be associated with higher postprandial circulating levels of AA, CCK and GLP-1, compared with an isoenergetic casein preload. These findings identify larger post-absorptive increases in plasma AA together with both CCK-mediated and GLP1-mediated satiety mechanisms as potential mediators of the increased satiety response to whey. Further work will be needed to identify the relative importance of these responses. It is difficult to separate these hormonal and metabolite responses, since they will always occur together in a natural context, and in reality their influences on satiety probably complement each other. Regardless of the physiological mechanisms for increased satiety following whey protein compared with casein, these findings raise the opportunity for research into the development of new food products that differ in their satiating capacity. These could include foods containing 'fast' proteins that would increase the satiating capacity of the food, thus helping in the treatment of obesity and weight management, as well as less satiating foods containing 'slow' proteins that might be useful in clinical nutrition as sip feeds for elderly or sick patients where increased food intake is desired.

\section{References}

Ballinger AB \& Clark ML (1994) L-Phenylalanine releases cholecystokinin (CCK) and is associated with reduced food intake in humans: evidence for a physiological role of CCK in control of eating. Metabolism 43, 735-738.

Barkeling B, Rossner S \& Bjorvell H (1990) Effects of a highprotein meal (meat) and a high-carbohydrate meal (vegetarian) on satiety measured by automated computerised monitoring of subsequent food intake, motivation to eat and food preferences. International Journal of Obesity 14, 743-751.

Beardshall K, Deprez P, Playford RJ, Alexander M \& Calam J (1992) Effect of chymotrypsin on human cholecystokinin release - use of clostripan in the validation of a new radioimmunoassay. Regulatory Peptides 40, 1-12.

Billeaud C, Guillet J \& Sandler B (1990) Gastric emptying in infants with or without gastro-oesophageal reflux according to the type of milk. European Journal of Clinical Nutrition 44, 577-583.

Boirie Y, Dangin M, Gachon P, Vasson M, Maubois J \& Beaufrere B (1997) Slow and fast dietary proteins differently modulate postprandial protein accretion. Proceedings of the National Academy of Sciences of the United States of America 94, 14930-14935.

Booth DA, Chase A \& Campbell AT (1970) Relative effectiveness of protein in the late stages of appetite suppression in man. Physiology and Behavior 5, 1299-1302.

Campfield LA \& Smith FJ (1990) Transient declines in blood glucose signal meal initiation. International Journal of Obesity 14, $15-33$.

De Castro JM (1987) Macronutrient relationships with meal patterns and mood in the spontaneous feeding behaviour of humans. Physiology and Behavior 39, 561-569.

Elliott RM, Morgan LM, Tredger JA, Deacon S, Wright J \& Marks V (1993) GLP-1 (7-36) amide and glucose-dependent insulinotropic polypeptide secretion in response to nutrient ingestion in man: acute post-prandial and $24 \mathrm{~h}$ secretion patterns. Journal of Endocrinology 138, 159-166.

Flint A, Raben A, Blundell JE \& Astrup A (2000) Reproducibility, power and validity of visual analogue scales in assessment of appetite. International Journal of Obesity 24, 38-48.

Gannon MC, Nuttal FQ, Neil BJ \& Westphal SA (1988) The insulin and glucose responses to meals of glucose plus various proteins in type II diabetic subjects. Metabolism 37, 1081-1088.

Gibbs J \& Smith GP (1977) Cholecystokinin and satiety in rats and rhesus monkeys. American Journal of Clinical Nutrition 30, $758-761$.

Go VLW, Hofman AF \& Summerskill WHJ (1970) Pancreozymin bioassay in man based on pancreatic enzyme secretion: potency of specific amino acids and other digestive products. Journal of Clinical Investigation 49, 1558-1564.

Green SM \& Blundell JE (1996) Subjective and objective indices of the satiating effect of foods. Can people predict how filling a food will be? European Journal of Clinical Nutrition 50, 798-806.

Gutzwiller JP, Goke B, Drewe J, Hildebrand P, Ketterer S, Handschin D, Winterhalder R, Conen D \& Beglinger C (1999) Glucagon-like peptide-1: a potent regulator of food intake in humans. Gut $\mathbf{4 4}, 81-86$.

Hampton SM \& Whithey L (1993) Monitoring B cell responses in 
obese and normal weight subjects; a pilot study. Diabete and Metabolisme 19, 582-585.

Heading RC, Nimmo J, Prescott LF \& Tothill P (1973) The dependence of paracetamol absorption on the rate of gastric emptying. British Journal of Pharmacology 47, 415-421.

Hill AJ \& Blundell JE (1988) Role of amino acids in appetite control in man. In Amino Acid Availability and Brain Function in Health and Disease. Proceedings of the Advanced Research Workshop NATO ASI Series H, pp. 239-248 [G Huether, editor]. Berlin, New York: Springer-Verlag.

Hill AJ \& Blundell JE (1990) Comparison of the action of macronutrients on the expression of appetite in lean and obese human subjects. Annals of the New York Academy of Sciences 597, $529-531$.

Hill AJ, Rogers PJ \& Blundell JE (1995) Techniques for the experimental measurement of human eating behaviour and food intake: a practical guide. International Journal of Obesity 19, 361-375.

Hopman WPM, Jansen JBMJ \& Lamers CBHW (1985) Comparative study of the effects of equal amounts of fat, protein and starch on plasma cholecystokinin in man. Scandinavian Journal of Gastroenterology 20, 843-847.

Hrboticky N, Leiter LA \& Anderson GH (1985) Effects of Ltryptophan on short-term food-intake in lean men. Nutrition Research 5, 595-607.

Hubbard R, Kosch CL, Sanchez A, Sabate J, Berk L \& Shavlik G (1989) Effect of dietary protein on serum insulin and glucagon levels in hyper- and normocholesterolemic men. Atherosclerosis 76, 55-61.

Johnstone AM, Stubbs RJ \& Harbron CG (1996) Effect of overfeeding macronutrients on day-to-day food intake in man. European Journal of Clinical Nutrition 50, 418-430.

Lang V, Bellisle F, Alamowitch C, Craplet C, Bornet FRJ, Slama G \& Guy-Grand B (1999) Varying the protein source in mixed meal modifies glucose, insulin and glucagon kinetics in healthy men, has weak effects on subjective satiety and fails to affect food intake. European Journal of Clinical Nutrition 53, 959-965.

Lang V, Bellisle F, Oppert J-M, Craplet C, Bornet FRJ, Slama G \& Guy-Grand B (1998) Satiating effect of proteins in healthy subjects: a comparison of egg albumin, casein, gelatin, soy protein, pea protein, and wheat gluten. American Journal of Clinical Nutrition 67, 1197-1204.

Latner JD \& Schwartz M (1999) The effects of a high-carbohydrate, high-protein or balanced lunch upon later food intake and hunger ratings. Appetite 33, 119-128.

Lieverse RJ, Jansen JBMJ, Masclee AAM \& Lamers CBHW (1994) Satiety effects of cholecystokinin in humans. Gastroenterology 106, 1451-1454.

Long SJ, Jeffcoat AR \& Millward DJ (2000) Effect of habitual dietary-protein intake on appetite and satiety. Appetite 35, 79-88.

Mellinkoff SM, Frankland M, Boyle D \& Greipel M (1956) Relationship between serum amino acid concentration and fluctuations in appetite. Journal of Applied Physiology 8, $535-538$.

Miller MJS, Witherly SA \& Clark DA (1990) Casein: a milk protein with diverse biologic consequences. Proceedings of the Society for Experimental Biology and Medicine 195, 143-159.

Morgan LM, Hampton SM, Tredger JA, Cramb R \& Marks V (1988) Modifications of gastric inhibitory polypeptide (GIP) secretion in man by a high-fat diet. British Journal of Nutrition 59, 373-380.

Morgan LM, Morris BA \& Marks V (1978) Radioimmunoassay of gastric inhibitory polypeptide. Annals of Clinical Biochemistry 15, 172-177.

Muurahainen NE, Kissileff HR \& Pi-Sunyer FX (1988) L-Phenylalanine and L-tryptophan reduce food intake when given with a food preload. American Journal of Clinical Nutrition 47, 774.

Penman E, Wass JAH, Medback S, Morgan LM, Lewis J, Besser GM \& Rees LH (1981) Response of circulating somatostatin to nutritional stimuli in normal subjects. Gastroenterology 81, 692-699.

Porrini M, Santangelo A, Crovetti R, Riso P, Testolin G \& Blundell JE (1997) Weight, protein, fat and timing of preloads affect food intake. Physiology and Behavior 62, 563-570.

Rogers PJ (1993) The experimental investigation of human eating behaviour. In Human Psychopharmacology, vol. 4, pp. 123-142 [I Hindmarch and PD Stonier, editors]. London: John Wiley \& Sons Ltd.

Rogers PJ, Burley VJ, Alikhanizadeh LA \& Blundell JE (1995) Postingestive inhibition of food intake by aspartame: importance of interval between aspartame administration and subsequent eating. Physiology and Behavior 57, 489-493.

Schirra J, Katschinski M, Weldmann C, Schafer T, Wank U, Arnold R \& Goke B (1996) Gastric emptying and release of incretin hormones after glucose ingestion in humans. Journal of Clinical Investigation 97, 92-103.

Stubbs RJ, Hughes DA, Johnstone AM, Rowley E, Reid C, Elia M, Stratton R, Delargy H, King N \& Blundell JE (2000) The use of visual analogue scales to assess motivation to eat in human subjects: a review of their reliability and validity with an evaluation of new hand-held computerized systems for temporal tracking of appetite ratings. British Journal of Nutrition 84, 405-415.

Stubbs RJ, Van Wyk MCW, Johnstone AM \& Harbron CG (1996) Breakfast high in protein, fat or carbohydrate: effect on withinday appetite and energy balance. European Journal of Clinical Nutrition 50, 409-417.

Uhe AM, Collier GR \& O'Dea K (1992) A comparison of the effects of beef, chicken and fish protein on satiety and amino acid profiles in lean male subjects. Journal of Nutrition 122, 467-472.

Vandewater K \& Vickers Z (1996) Higher protein foods produce greater sensory specific satiety. Physiology and Behavior 59, $579-583$.

van Strien T, Frijters JER, Bergers GPA \& Defares PB (1986) The Dutch Eating Behaviour Questionnaire (DEBQ) for assessment of restrained, emotional, and external eating behaviour. International Journal of Eating Disorders 5, 295-315.

Verdich C, Flint A, Gutzwiller JP, Näslund E, Beglinger C, Hellström PM, Long SJ, Morgan LM, Holst JJ \& Astrup A (2001) A meta-analysis of the effect of glucagon-like peptide-1 (7-36) amide on ad libitum energy intake in humans. Journal of Clinical Endocrinology and Metabolism 86, 4382-4389.

Woods SC \& Porte D Jr (1983) The role of insulin as a satiety factor in the central nervous system. Advances in Metabolic Disorders 10, 457-467.

Wurtman RJ, Hefti F \& Melamed E (1981) Precursor control of neurotransmitter synthesis. Pharmacological Reviews 32, $315-335$. 